\title{
Sulfonylurea Glimepiride: A Proven Cost Effective, Safe and Reliable War Horse in Combating Hyperglycemia in Type 2 Diabetes
}

\author{
Udaya M. Kabadi \\ Broadlawns Medical Center, Des Moines, lowa; Des Moines University, Des Moines, lowa and University of \\ lowa, lowa City, Iowa, USA \\ Email: ukabadi@gmail.com
}

Received 19 September 2015; accepted 13 October 2015; published 16 October 2015

Copyright (C) 2015 by author and Scientific Research Publishing Inc. This work is licensed under the Creative Commons Attribution International License (CC BY). http://creativecommons.org/licenses/by/4.0/

(c) (i) Open Access

\section{Abstract}

Recently, a debate has been raised regarding the place and the role of sulfonylureas (SU) amongst the armamentarium of drugs available for treatment of hyperglycemia in subjects with type 2 diabetes mellitus. With the advent of new drugs, SUs are being relegated and denigrated by some authorities contrary to present recommendations by various organizations e.g. American Diabetes Association, European Association for the Study of Diabetes and International Diabetes Federation. In this article, the advantages of SUs over the new agents in terms of their well established and proven better efficacy as well as their short term and long term (over 50 years) safety based on extensive literature data are documented. Moreover, lower costs of SUs render them to be far more cost effective when compared to new agents and therefore make them affordable in many regions of the world. Additionally, SUs are probably the initial drugs of choice in lean subjects with prediabetes and type 2 diabetes because they are the most effective secretogogues and major pathophysiologic mechanism of altered glucose metabolism in lean subjects is the decline in insulin secretion and not rising insulin resistance. Furthermore, SUs are also the most cost effective 2 nd line agents in obese subjects with type 2 diabetes on lapse of glycemic control while receiving metformin. Finally, with progression of the disorder, the most cost effective combination of 2 oral agents in conjunction with basal insulin remains to be metformin and SUs. Many studies have documented a significantly greater extra pancreatic effect of glimepiride in comparison to other SUs probably because of its unique property in enhancing insulin sensitivity in conjunction with its ability to stimulate both 1 st and 2 nd phase insulin secretion. These characteristics may contribute to its greater efficacy with lesser hypoglycemia when compared with other SUs. Lack of hypoglycemic effect of metabolites of glimepiride may also be responsible for lesser hypoglycaemia. Moreo- 
ver, metabolism of glimepiride performed partially by the liver and partially by the kidneys may render it suitable and adaptable to be administered safely in subjects with hepatic or renal dysfunctional as well as elderly. Finally, the documentation of its pleiotropic effects in lowering of cardiovascular surrogate markers, improving thrombotic milleau by reducing platelet aggregation factors along with improvement in glycemic control and its preferential binding to SU receptors on the pancreatic beta cells rather than myocardium may be responsible for providing better cardiovascular outcomes in comparison to other SUS and thus make it a better choice amongst SUs in subjects with or without presence of cardiovascular disease. Additionally, once daily administration because of lasting efficacy for 24 hours based on its half life is likely to enhance compliance on the part of patients and assist in attaining and maintaining desirable glycemic control. Therefore, SUs still deserve to be major players in management of hyperglycemia in subjects with type 2 diabetes mellitus and glimepiride may be the best choice amongst SUs because of its long term record regarding efficacy and safety in diverge population of subjects with type 2 diabetes mellitus.

\section{Keywords}

Type 2 Diabetes, Sulfonylureas (SU)

\section{Introduction}

"Sulfonylurea" (SU) debate was recently published in Journal "Diabetes Care" [1] [2]. Ganuth [2] affirms that newer agents are as effective as SUs although premarketing clinical trials have documented markedly greater lowering of A1c from baseline level $(25 \%-30 \%)$ by older drugs, sulfonylureas and metformin in drug naïve subjects in comparison to many newer agents (Table 1) as well as SGLT 2 inhibitors (7\% - 12\%) [3]-[16]. In fact in UKPDS [17]-[19]) SUs, glibenclamide and chlorpropamide were more effective in all comers, and obese and non-obese subjects when compared with metformin in obese subjects (Table 1). The greater efficacy of sulfonylureas in comparison to newer drugs, e.g. DPP4 inhibitors or GLP1 analogs in drug naïve subjects may be attributed to their ability to lower both the fasting and postprandial plasma glucose by stimulating both 1st and 2nd phase postprandial insulin secretion whereas DPP4 inhibitors and GLP1 analogs stimulate only the 1st phase insulin secretion and thus are devoid of much effect on fasting plasma glucose levels [20]-[26]. In fact, the major alternative mechanism of lowering post prandial glycemia by DPP4 inhibitors is documented to be via decrease in glucagon secretion rather than enhancement of insulin release by beta cells [27]-[40]. Moreover, postprandial glycemia is closely correlated to fasting plasma glucose [41]. Therefore, SUs lower post prandial glycemia to a greater degree when compared with DPP4 inhibitors and GLP 1 analogs. Furthermore, the decline in fasting plasma glucose induced by SUs results in superior efficacy in lowering overall diurnal glycemia with a greater reduction in HbA1c as described previously [11]. Finally, Glimepiride induces a rise in both 1st and 2nd phase postprandial insulin secretion as well as improvement in insulin sensitivity and therefore appears to be more effective than other SUs [11] [26].

In contrast, an equal or greater lowering of $\mathrm{HbAlc}$ by newer agents compared to SUs and even metformin in subjects with prolonged duration of diabetes described by Genuth [2] may be attributed to several reasons. Many

Table 1. UKPDS: glycemic control (median HbA1C) and median change (r) in body weight (BWKG) over ten years [17] [19].

\begin{tabular}{ccc}
\hline Treatment & Median HbA1C & Median r BW \\
\hline Chlorpropamide & 6.7 & 5.1 \\
Glyburide & 7.2 & +4.2 \\
Insulin & 7.1 & +6.0 \\
Metformin & 7.4 & +3.0 \\
Conventional & 8.0 & +2.5 \\
\hline
\end{tabular}


published clinical trials have compared the efficacy of the maximum daily dose of newer agents: DPP4 inhibitors, GLP1 analogs and SGLT2 inhibitors with either a minimally effective or submaximal recommended daily dose of SUs [27]-[40] [42]-[46]. The reason for administration of SUs in a minimally effective or sub maximal daily dose, e.g. glimepiride, $1-6 \mathrm{mg}$ in these comparative trials may be explained by the selection of subjects with average baseline $\mathrm{HbAlc}$ between $8 \%$ and $8.5 \%$ prior to initiation of drugs because the maximal daily dose of newer agents is established to lower HbAlc by $10 \%-15 \%$ whereas the maximum daily dose of glimepiride is documented to lower $\mathrm{HbAlc}$ by approximately $25 \%$ [11] and therefore a much lower than the maximum daily dose is adequate to obtain a comparable reduction in HbAlc. Moreover, many of these recent comparative clinical trials are conducted by using generic SU, e.g. glimepiride probably with variable bioavailability and variable efficacy. Also, many of these studies are conducted in "clinical trial mills" with same cadre of subjects in their collective databases as recently documented [47] [48]. Thus, recycling of the same subjects hopping from one trial to another may have skewed the "real and accurate" comparative efficacy [48]. Finally, reduced efficacy of older drugs in these "comparative efficacy" trials when compared to the efficacy documented in their "premarketing" trials may be attributed to "drug receptor interaction". Previous long term or repeated exposure is likely to induce "down regulation" as well as decreased affinity of the receptors of older drugs resulting in decreased efficacy whereas lack of exposure causes "up regulation" and maximal affinity of the receptors for the newer agents at their initiation with consequential maximum efficacy. Therefore, the optimal and appropriate methodology is the comparative trials in drug naïve subjects with the drugs being used either as monotherapy or as a second line agents added to metformin as designed in the ongoing "Grade" trial [49]. Finally, even if the similar efficacies of newer agents are factual, as suggested by Ganuth [2], as per his own admission, SUs are less expensive, thus rendering them to be distinctly more cost effective than newer agents.

\section{Discussion}

Long term safety of SUs especially in terms of cardiovascular outcomes and all cause mortality has been questioned in several epidemiologic studies mostly through registry data [50]-[53]. However, all these studies are retrospective in nature. Moreover, the other risk factors such as the degree of glycemic control, lipid profiles, duration of diabetes, age of the patients and presence of hypertension and other complications including autonomic neuropathy and renal dysfunction may have impacted these results and hence conclusions. In contrast, the prospective clinical trials have established long term safety of SUs regarding cardiovascular outcomes including occurrence of congestive heart failure as well as all cause mortality [54]-[62]. In fact, UKPDS showed that SUs specifically glibenclamide and chlorpropamide lowered the rate of both micro and macrovascular complications in the original trial as well as during the follow up period of 10 years described as a "Legacy Effect" [17] [18] [56]. Moreover, newer SUs, glipizide, glyclazide and glimeperide are documented to be as or more effective and safer than glibenclamide in terms of cardiovascular outcomes in several studies with glimeperide being the leader [61] [63]-[67]. The superiority of glimeperide over other SUs may be attributed to its ability to improve several surrogate cardiovascular qrisk markers [67]-[75]. Unfortunately though, lack of increase or decrease in cardiovascular outcomes has become the standard of cardiovascular safety as documented in recent trials with newer agents [15] [16] [76]-[84] rather than lowering of these outcomes with improvement in glycemic control as was documented in UKPDS and Advance studies [17] [18] [55]-[57]. Moreover, the period of observation for safety for newer agents is comparatively markedly shorter when compared with the studies with SUs.

Other valid concerns regarding SUs are their role in induction of hypoglycemia and weight gain. Severe hypoglycemia as defined by diabetes organizations is documented to be extremely rare with SUs [56] [57] [85][91]. Non severe hypoglycemia did occur even in metformin treated subjects in UKPDS as well, although the occurrence was significantly lower in comparison to subjects receiving SUs [18]. Similarly, in UKPDS, weight gain was documented in all groups of subjects over a period of $10-15$ years including obese subjects treated with metformin [17] [18]. Both the occurrences of hypoglycemia and weight gain appeared to be dependent on the degree of long term glycemic control and were greater with better glycemic control in both non obese and obese subjects treated with SUs in comparison to obese subjects receiving metformin (Table 2); metformin was not used in nonobese subjects in this study [17] [18]. Moreover, newer SUs, glipizide, glyclazide and glimeperide are documented to be safer in terms of hypoglycemia in comparison to glibenclamide used in UKPDS [55] [57] [90] [91].

Thus, newer SUs, glipizide, glyclazide and glimeperide are documented to be as or more effective and safer in terms of both hypoglycemia and cardiovascular outcomes in several studies with glimeperide being the leader 
Table 2. Comparison of efficacy in drug naïve subjects with type 2 diabetes mellitus [11].

\begin{tabular}{|c|c|c|c|c|c|}
\hline Drug & Dose $\mathrm{mg} / \mathrm{day}$ & Pre-RX HbA1C \% & Post-RX HbA1C \% & r HbA1C \% & r\% HbA1C \\
\hline Glipizide & 20 & 8.8 & 7.1 & 1.7 & 19 \\
\hline Glimepiride & 8 & $9.1(13.2)$ & $6.7(7.6)$ & $2.4(5.6)$ & 2642 \\
\hline Metformin & 2550 & 8.4 & 7.0 & 1.4 & 16 \\
\hline Avandia & 8 & 8.5 & 7.3 & 1.2 & 14 \\
\hline Actos & 45 & 10.0 & 8.1 & 1.9 & 19 \\
\hline Prandin & 12 & 8.5 & 7.8 & 0.6 & 7 \\
\hline Starlix & 360 & 8.3 & 7.6 & 0.8 & 10 \\
\hline GLP1 analogs & Variable & 8.2 & 6.8 & 1.4 & 15 \\
\hline Gliptins & Variable & 8.0 & 7.2 & 0.8 & 10 \\
\hline
\end{tabular}

[61] [63]-[75] [87] [90] [91].

In contrast, long term efficacy and safety of newer drugs remains to be established. In fact, SGLT 2 inhibitors possess much lesser efficacy with far greater costs and undesirable adverse effects when compared to SUs. The undesirable adverse effects of SGLT2 inhibitors include dehydration and orthostatic hypotension due to persistent glycosuria resulting in elevations in serum urea nitrogen, creatinine, potassium with an occasional manifestation of severe hypercalcemia and hypernatremia [15] [16] [92]. Moreover, hypercalciuria as well as uricosuria accompanying glycosuria in presence of dehydration may facilitate formation of renal calculi [93]. Another recent report documented increased prevalence of fractures and osteoporosis with use of these agents and attributed this finding to rise in PTH and FGF 23 [94]. We believe that a simple pathophysiology for increase in osteoporosis and fractures is hypercalciuria and phosphaturia accompanying glycosuria induced by these drugs. Additionally high prevalence of genitourinary sepsis secondary to persistent glycosuria should not be acceptable because of a consequential decline of quality of life as well as the cost of management of these infections. Furthermore, glycosuria with resultant polyuria or pollakiuria is likely to induce a decline in quality of life even without occurrence of genitourinary infections especially in elderly men with prostatism and postmenopausal women with urinary incontinence, the population with the highest prevalence of type 2 Diabetes. In fact, the major precipitant in induction of DKA in many of the subjects reported in the recent caution by the U.S Food and Drug Administration (FDA) and European Medicine Agency (EMA) was urinary sepsis [95] [96], a frequent manifestation in subjects with uncontrolled hyperglycemia because of concurrent presence of immunosupression. The onset of ketoacidosis may also be attributed to increased lipolysis induced by elevated plasma glucagon levels required to promote hepatic glucose production to compensate for glycosuria [97]. The rise in plasma glucagon is also well established to facilitate lipolysis with onset of ketonemia and consequential ketonuria as documented in several recent clinical trials using these agents [15] [16] [98]. FDA also noted that many of these subjects manifested ketoacidosis without hyperglycemia as documented in another recent report [99]. Serum lipase and amylase concentrations were not determined in these subjects in spite of the presence of symptoms, e.g. nausea, vomiting and abdominal pain indicative of acute pancreatitis which has been reported in several case studies [100]-[102]. Therefore, it is likely that Euglycemic Ketoacidosis described in these subjects [95] [96] [99] may be in fact "Kabadi Syndrome of Pancreatic Ketoacidosis" induced by markedly elevated circulating lipase concentration [103]-[106] of acute pancreatitis, the diagnosis which was probably missed in these subjects [99]. Moreover, a pathophysiologic mechanism is also implicated in occurrence of Ketoacidosis on administration of SGLT2 inhibitors [107]-[109]. However, manufacturers of these drugs refute the significance of these reports by FDA and EMA based on the retrospective analysis of pre marketing clinical trials [110] [111]. The lack of significant occurrence of Ketoacidosis in these trials as compared to the other data may be explained by the fact that the participating subjects were healthier because of their selection bias based on several inclusion and exclusion criteria when compared with the population of subjects with type 2 Diabetes in clinical practice. Moreover, the opinions of investigators conducting these clinical trials require scrutiny [111]. Finally, rise in serum LDL and increase in serum viscosity secondary to dehydration is likely to induce a hypercoaggulable 
milleu with increased susceptilibity for macrovascular events, e.g. strokes documented in even short term studies with Canagliflozin [15] [16] [112]. Finally, outcomes of the long term exposure of the genitourinary tract to hyperglycemic hyperosmolar urine are unkown although the increased prevalence of bladder cancer has been reported in early clinical trials using Depagliflozin [113]-[115]. I believe that constant presence of sugar, the most efficient fuel for cell growth may have promoted growth of bladder cancer in situ and rendered it to be manifested rather than initiating the onset. Therefore, the safety of these agents is questionable in the short term and remains to be established in the long term.

In UKPDS, SUs, glibenclamide and chlorpropamide delayed beta cell failure in more subjects and for a longer period of time in both non obese in comparison to subjects treated with conventional( diet and exercise) program as well as obese subjects in comparison to obese subjects treated with Metformin (Figure 1 and Figure 2) [17] [18]. This interesting finding may be attributed to improvement in beta cell function from $50 \%$ at diagnosis to $80 \%$ by the end of 1 st year by SUs (Figure 3) [116]. In contrast, beta cell function continued to decline in subjects receiving metformin [116]. I believe that progressive beta cell failure is reversible and not universal as documented on attaining and maintaining weight loss following long term life style intervention as well as bariatric procedures [117]-[124]. Moreover, persistent progressive beta cell failure may be secondary to fibrosis of islets caused by micrvascular disease analogous to other microvascular complications of diabetes, e.g. retinopathy, nephropathy and neuropathy [125] [126]. Therefore, sustained, prolonged and permanent preservation of desirable glycemic control is likely to delay onset of beta cell failure similar to the other microvascular complications as demonstrated in recent "Origin" trial [127] [128]. We have recently documented better efficacy of Glimepiride in delaying progression to diabetes for a longer period of time and in fewer lean subjects without occurrence of hypoglycemia in comparison to treatment with metformin in obese subjects with prediabetes [129]. The efficacy of glimepiride may be attributed to the decline in insulin secretion being the major pathophysiologic mechanism in onset of impaired glucose tolerance and type 2 diabetes in lean subjects [130]. In the same study, we observed similar improvements in lipid pattern and other cardiovascular surrogate markers with no deaths and $\mathrm{CV}$ outcomes in both lean and obese groups with prediabetes [67].

I believe that improvements in lipids and CV surrogate markers by both drugs, glimepiride and metformin described in this and several other studies are likely to be induced by improvement in functioning of cells and tissues by enhanced entry of glucose, the most effective fuel. In contrast, long term efficacy and safety of newer drugs remains to be established.

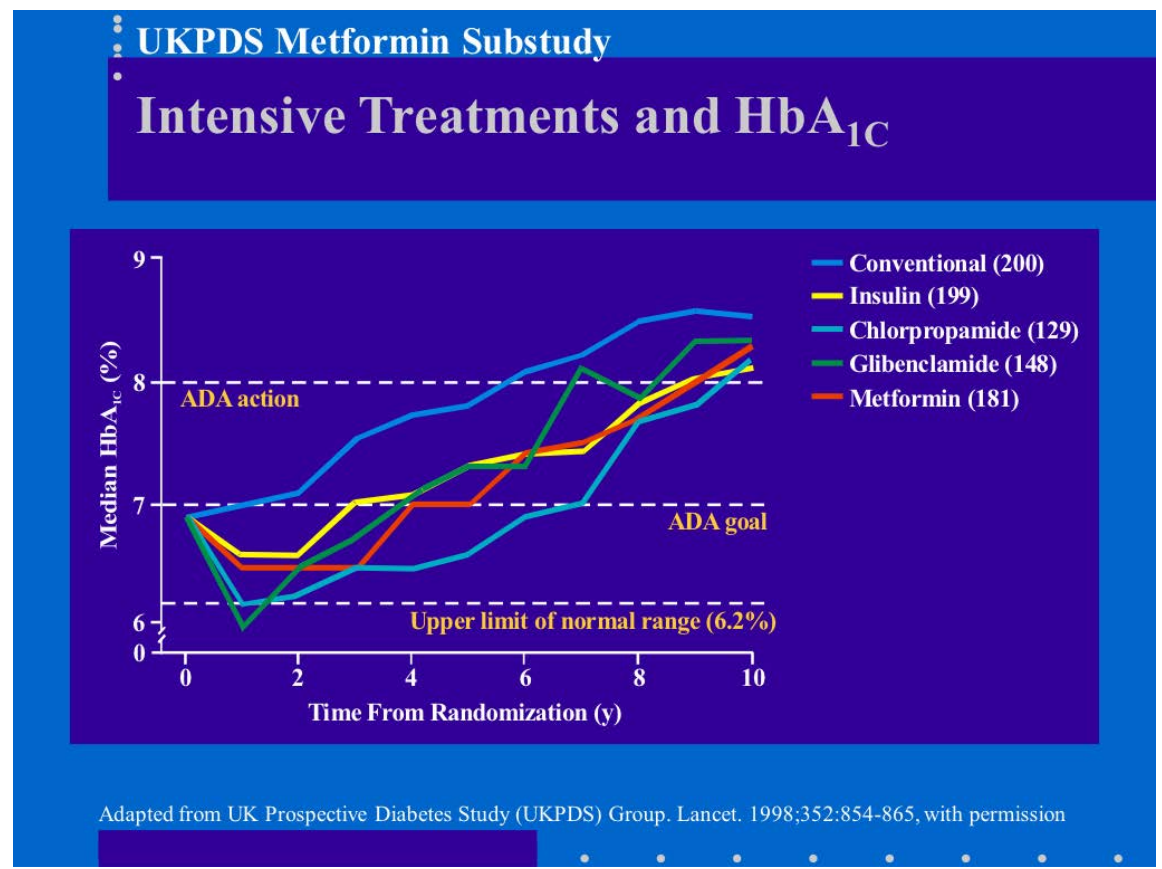

Figure 1. Maintenance of A1c $<7 \%$ for longer duration in subjects treated with SUs in comparison to metformin in UKPDS [17] [18]. 


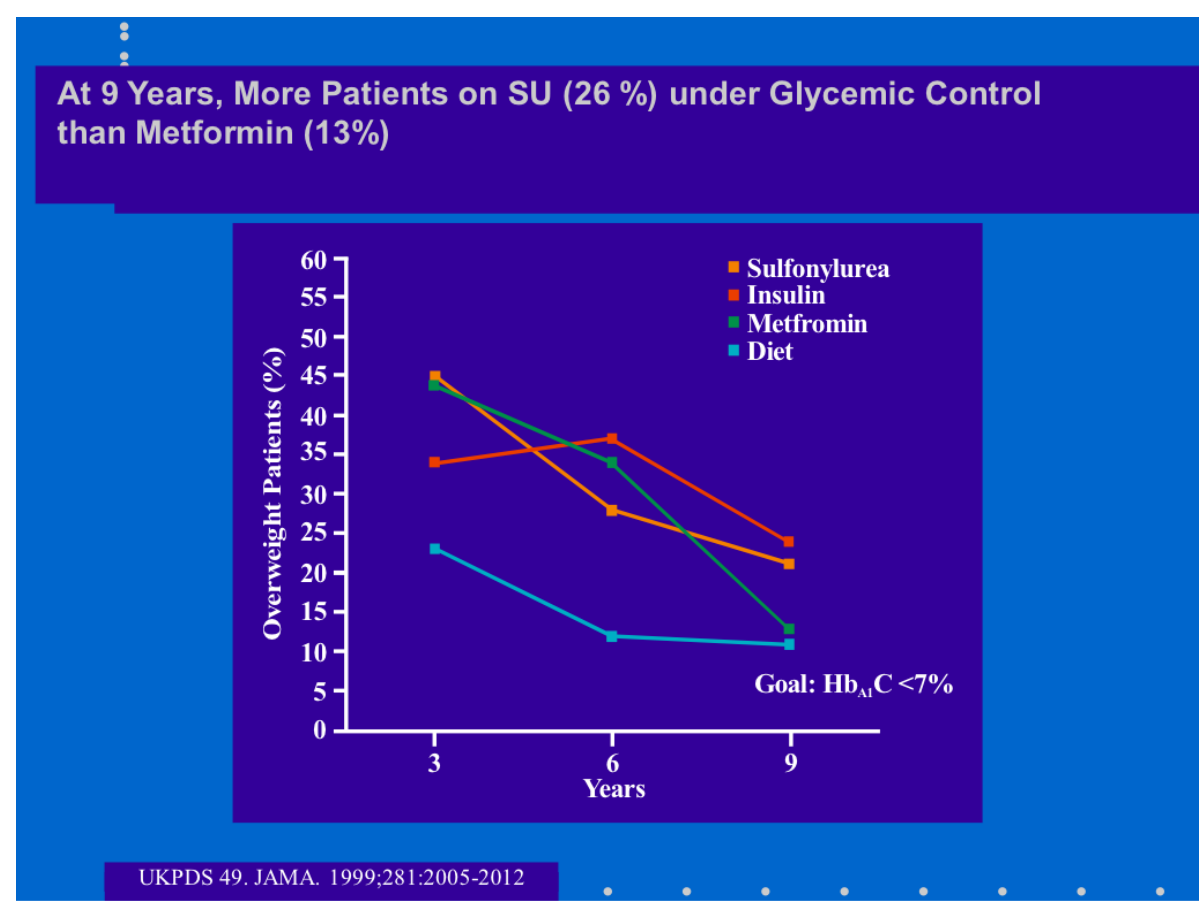

Figure 2. More subjects treated with SUs with desirable glycemic goal (7\%) in comparison to metformin or conventional (diet and exercise) at 9 years [17] [18].
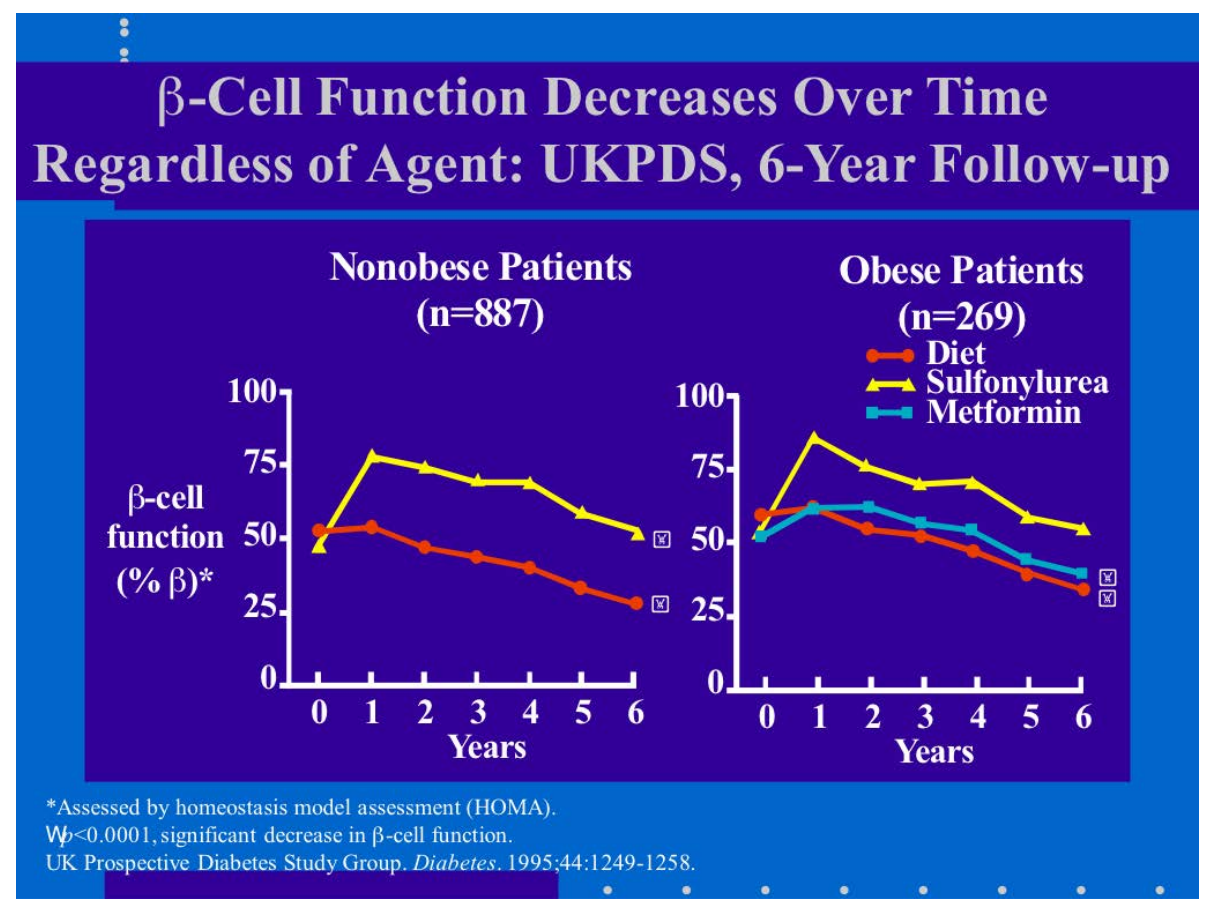

Figure 3. Greater beta cell function at 6 years in non obese subjects treated with SUs in comparison to conventional (diet and exercise) and in obese subjects in comparison to metformin [116].

Finally, therapy with SUs by themselves, especially glimepiride or with metformin when administered concurrently with basal insulin has been shown to be more cost effective when compared with combination of basal insulin with any other drug e.g. glitazones, DPP4 inhibitors or GLP1 analogs as a single agent. This outcome may be attributed to lower cost of SU and metformin as compared to other drugs including glitazones, DPP4 in- 
hibitors and GLP1 analogs [11] as well as the lower daily dose of insulin required to achieve desirable glycemic control [85]-[87] [131]-[158]. In fact, adjunctive administration of both glimepiride and metformin is documented to lower daily insulin dose, basal type as well NPH or premixed insulins more than when these drugs are used alone [134]-[142]. The lower the daily dose, the lesser the number of peaks of insulin, lower is the hypoglycemic events and lesser the weight gain [134]-[144] [157] [158]. Finally a recent study also documented significantly longer delay for requirement of addition of insulin with SUs when compared with DPP4 inhibitors and GLP1 analogs [159].

In the final analysis, SUs have stood the test of time for over 50 years in terms of efficacy and safety whereas the long term efficacy and safety of newer drugs remain to be established. Moreover, SUs are thought to provide and maintain the better quality of life when compared with newer agents [159] and are distinctly far more cost effective than newer agents.

\section{Conclusion}

Therefore, SUs must remain as 1st line agents especially in management of non-obese subjects with type 2 diabetes since the dominant pathophysiologic mechanism is the decline in insulin secretion in this population [130]. Moreover, SUs remain the 2nd line most cost effective viable oral option in obese subjects on the lapse of glycemic control while receiving metformin since the addition of newer drugs is less likely to achieve the desirable glycemic goal of $6.5 \%-7.0 \%$ due to their documented lesser efficacy in several studies [11]. Finally, in many regions of the world with markedly rising prevalence of diabetes e.g. Asia, Africa and South America with countries like China and India leading the pack [160], SUs remain the drugs of choice either as a 1st line drug in nonobese population and 2nd line agent in obese subjects with type 2 diabetes because of their well established efficacy, safety and mainly affordability in these regions and countries.

\section{References}

[1] Abrahamson, M.J. (2015) Should Sulfonylureas Remain an Acceptable First-Line Add-On to Metformin Therapy in Patients with Type 2 Diabetes? Yes, They Continue to Serve Us Well! Diabetes Care, 38, 166-169. http://dx.doi.org/10.2337/dc14-1945

[2] Genuth, S. (2015) Should Sulfonylureas Remain an Acceptable First-Line Add-On to Metformin Therapy in Patients with Type 2 Diabetes? No, It's Time to Move on! Diabetes Care, 38, 170-175. http://dx.doi.org/10.2337/dc14-0565

[3] Simonson, D.C., Kourides, I.A., Feinglos, M., Shamoon, H. and Fischette, C.T. (1997) Efficacy, Safety, and Dose-Response Characteristics of Glipizide Gastrointestinal Therapeutic System on Glycemic Control and Insulin Secretion in NIDDM. Results of Two Multicenter, Randomized, Placebo-Controlled Clinical Trials. The Glipizide Gastrointestinal Therapeutic System Study Group. Diabetes Care, 20, 597-606. http://dx.doi.org/10.2337/diacare.20.4.597

[4] Schade, D.S., Jovanovic, L. and Schneider, J. (1998) A Placebo-Controlled, Randomized Study of Glimepiride in Patients with Type 2 Diabetes Mellitus for Whom Diet Therapy Is Unsuccessful. The Journal of Clinical Pharmacology, 38, 636-641. http://dx.doi.org/10.1002/j.1552-4604.1998.tb04471.x

[5] DeFronzo, R.A. and Goodman, A.M. (1995) Efficacy of Metformin in Patients with Non-Insulin-Dependent Diabetes Mellitus. The Multicenter Metformin Study Group. The New England Journal of Medicine, 333, 541-549. http://dx.doi.org/10.1056/NEJM199508313330902

[6] Goldberg, R.B., Einhorn, D., Lucas, C.P., Rendell, M.S., Damsbo, P., Huang, W.C., Strange, P. and Brodows, R.G. (1998) A Randomized Placebo-Controlled Trial of Repaglinide in the Treatment of Type 2 Diabetes. Diabetes Care, 21, 1897-1903. http://dx.doi.org/10.2337/diacare.21.11.1897

[7] Holman, R.R., Cull, C.A. and Turner, R.C. (1999) A Randomized Double-Blind Trial of Acarbose in Type 2 Diabetes Shows Improved Glycemic Control over 3 Years (U.K. Prospective Diabetes Study 44). Diabetes Care, 22, 960-964. http://dx.doi.org/10.2337/diacare.22.6.960

[8] Horton, E.S., Clinkingbeard, C., Gatlin, M., Foley, J., Mallows, S. and Shen, S. (2000) Nateglinide Alone and in Combination with Metformin Improves Glycemic Control by Reducing Mealtime Glucose Levels in Type 2 Diabetes. Diabetes Care, 23, 1660-1665. http://dx.doi.org/10.2337/diacare.23.11.1660

[9] Aronoff, S., Rosenblatt, S., Braithwaite, S., Egan, J.W., Mathisen, A.L. and Schneider, R.L. (2000) Pioglitazone Hydrochloride Monotherapy Improves Glycemic Control in the Treatment of Patients with Type 2 Diabetes: A 6-Month Randomized Placebo-Controlled Dose-Response Study. The Pioglitazone 001 Study Group. Diabetes Care, 23, 16051611. http://dx.doi.org/10.2337/diacare.23.11.1605

[10] Phillips, L.S., Grunberger, G., Miller, E., Patwardhan, R., Rappaport, E.B. and Salzman, A. (2000) Rosiglitazone 
Clinical Trials Study Group. Once- and Twice-Daily Dosing with Rosiglitazone Improves Glycemic Control in Patients with Type 2 Diabetes. Diabetes Care, 24, 308-315. http://dx.doi.org/10.2337/diacare.24.2.308

[11] Kabadi, U.M. (2004) Cost-Effective Management of Hyperglycemia in Patients with Type 2 Diabetes Using Oral Agents. Managed Care, 13, 48-59.

[12] Madsbad, S., Schmitz, O., Ranstam, J., Jakobsen, G. and Matthews, D.R., NN2211-1310 International Study Group (2004) Improved Glycemic Control with No Weight Increase in Patients with Type 2 Diabetes after Once-Daily Treatment with the Long-Acting Glucagon-Like Peptide 1 Analog Liraglutide (NN2211): A 12-Week, Double-Blind, Randomized, Controlled Trial. Diabetes Care, 27, 1335-1342. http://dx.doi.org/10.2337/diacare.27.6.1335

[13] De Fronzo, R.A., Ratner, R.E., Han, J., Kim, D.D., Fineman, M.S. and Baron, A.D. (2005) Effects of Exenatide (Exendin-4) on Glycemic Control and Weight over 30 Weeks in Metformin-Treated Patients with Type 2 Diabetes. Diabetes Care, 28, 1092-1100. http://dx.doi.org/10.2337/diacare.28.5.1092

[14] Raz, I., Hanefeld, M., Xu, L., Caria, C., Williams-Herman, D. and Khatami, H., Sitagliptin Study 023 Group (2006) Efficacy and Safety of the Dipeptidyl Peptidase-4 Inhibitor Sitagliptin as Monotherapy in Patients with Type 2 Diabetes Mellitus. Diabetologia, 49, 2564-2571. http://dx.doi.org/10.1007/s00125-006-0416-Z

[15] Vasilakou, D., Karagiannis, T., Athanasiadou, E., Mainou, M., Liakos, A., Bekiari, E., Sarigianni, M., Matthews, D.R. and Tsapas, A. (2013) Sodium-Glucose Cotransporter 2 Inhibitors for Type 2 Diabetes: A Systematic Review and Meta-Analysis. Annals of Internal Medicine, 159, 262-274. http://dx.doi.org/10.7326/0003-4819-159-4-201308200-00007

[16] Kabadi, U.M. (2013) How Low Do We Fall to Lower Hemoglobin A1c? SGLT2 Inhibitors: Effective Drugs or Expensive Toxins! Journal of Diabetes Mellitus, 3, 199-201.

[17] UK Prospective Diabetes Study (UKPDS) Group (1998) Intensive Blood-Glucose Control with Sulphonylureas or Insulin Compared with Conventional Treatment and Risk of Complications in Patients with Type 2 Diabetes (UKPDS 33). The Lancet, 352, 837-853. http://dx.doi.org/10.1016/S0140-6736(98)07019-6

[18] UK Prospective Diabetes Study (UKPDS) Group (1998) Effect of Intensive Blood-Glucose Control with Metformin on Complications in Overweight Patients with Type 2 Diabetes (UKPDS 34). The Lancet, 352, 854-865. http://dx.doi.org/10.1016/S0140-6736(98)07037-8

[19] Kabadi, U.M. (2002) United Kingdom Prospective Diabetes Study: A Different Perspective. Endocrine Practice, 8, 6164. http://dx.doi.org/10.4158/EP.8.1.61

[20] Kolterman, O.G., Gray, R.S., Shapiro, G., Scarlett, J.A., Griffin, J. and Olefsky, J.M. (1984) The Acute and Chronic Effects of Sulfonylurea Therapy in Type II Diabetic Subjects. Diabetes, 33, 346-354. http://dx.doi.org/10.2337/diab.33.4.346

[21] Groop, L., Luzi, L., Melander, A., Groop, P.H., Ratheiser, K., Simonson, D.C. and DeFronzo, R.A. (1987) Different Effects of Glyburide and Glipizide on Insulin Secretion and Hepatic Glucose Production in Normal and NIDDM Subjects. Diabetes, 36, 1320-1328. http://dx.doi.org/10.2337/diab.36.11.1320

[22] Bitzén, P.O., Melander, A., Scherstén, B. and Wåhlin-Boll, E. (1988) The Influence of Glipizide on Early Insulin Release and Glucose Disposal before and after Dietary Regulation in Diabetic Patients with Different Degrees of Hyperglycaemia. European Journal of Clinical Pharmacology, 35, 31-37. http://dx.doi.org/10.1007/BF00555504

[23] Groop, L.C., Ratheiser, K., Luzi, L., Melander, A., Simonson, D.C., Petrides, A., Bonadonna, R.C., Widén, E. and DeFronzo, R.A. (1991) Effect of Sulphonylurea on Glucose-Stimulated Insulin Secretion in Healthy and Non-Insulin Dependent Diabetic Subjects: A Dose-Response Study. Acta Diabetologica, 28, 162-168. http://dx.doi.org/10.1007/BF00579720

[24] van Haeften, T.W., Veneman, T.F., Gerich, J.E. and van der Veen, E.A. (1991) Influence of Gliclazide on Glucose-Stimulated Insulin Release in Man. Metabolism, 40, 751-755. http://dx.doi.org/10.1016/0026-0495(91)90096-F

[25] Korytkowski, M., Thomas, A., Reid, L., Tedesco, M.B., Gooding, W.E. and Gerich, J. (2002) Glimepiride Improves Both First and Second Phases of Insulin Secretion in Type 2 Diabetes. Diabetes Care, 25, 1607-1611. http://dx.doi.org/10.2337/diacare.25.9.1607

[26] Kabadi, M.U. and Kabadi, U.M. (2004) Effects of Glimepiride on Insulin Secretion and Sensitivity in Patients with Recently Diagnosed Type 2 Diabetes Mellitus. Clinical Therapeutics, 26, 63-69. http://dx.doi.org/10.1016/S0149-2918(04)90006-9

[27] Ferrannini, E., Fonseca, V., Zinman, B., Matthews, D., Ahrén, B., Byiers, S., Shao, Q. and Dejager, S. (2009) FiftyTwo-Week Efficacy and Safety of Vildagliptin vs. Glimepiride in Patients with Type 2 Diabetes Mellitus Inadequately Controlled on Metformin Monotherapy. Diabetes, Obesity and Metabolism, 11, 157-166. http://dx.doi.org/10.1111/j.1463-1326.2008.00994.x

[28] Matthews, D.R., Dejager, S., Ahren, B., Fonseca, V., Ferrannini, E., Couturier, A., Foley, J.E. and Zinman, B. (2010) Vildagliptin Add-On to Metformin Produces Similar Efficacy and Reduced Hypoglycaemic Risk Compared with Glimepiride, with No Weight Gain: Results from a 2-Year Study. Diabetes, Obesity and Metabolism, 12, 780-789. 
http://dx.doi.org/10.1111/j.1463-1326.2010.01233.x

[29] Arechavaleta, R., Seck, T., Chen, Y., Krobot, K.J., O’Neill, E.A., Duran, L., Kaufman, K.D., Williams-Herman, D. and Goldstein, B.J. (2011) Efficacy and Safety of Treatment with Sitagliptin or Glimepiride in Patients with Type 2 Diabetes Inadequately Controlled on Metformin Monotherapy: A Randomized, Double-Blind, Non-Inferiority Trial. Diabetes, Obesity and Metabolism, 13, 160-168. http://dx.doi.org/10.1111/j.1463-1326.2010.01334.x

[30] Jeon, H.J. and Oh, T.K. (2011) Comparison of Vildagliptin-Metformin and Glimepiride-Metformin Treatments in Type 2 Diabetic Patients. Diabetes \& Metabolism Journal, 35, 529-535. http://dx.doi.org/10.4093/dmj.2011.35.5.529

[31] Srivastava, S., Saxena, G.N., Keshwani, P. and Gupta, R. (2012) Comparing the Efficacy and Safety Profile of Sitagliptin versus Glimepiride in Patients of Type 2 Diabetes Mellitus Inadequately Controlled with Metformin Alone. Journal of the Association of Physicians of India, 60, 27-30.

[32] Gallwitz, B., Rosenstock, J., Rauch, T., Bhattacharya, S., Patel, S., von Eynatten, M., Dugi, K.A. and Woerle, H.J. (2012) 2-Year Efficacy and Safety of Linagliptin Compared with Glimepiride in Patients with Type 2 Diabetes Inadequately Controlled on Metformin: A Randomised, Double-Blind, Non-Inferiority Trial. The Lancet, 380, 475-483. http://dx.doi.org/10.1016/S0140-6736(12)60691-6

[33] Muscelli, E., Casolaro, A., Gastaldelli, A., Mari, A., Seghieri, G., Astiarraga, B., Chen, Y., Alba, M., Holst, J. and Ferrannini, E. (2012) Mechanisms for the Antihyperglycemic Effect of Sitagliptin in Patients with Type 2 Diabetes. The Journal of Clinical Endocrinology \& Metabolism, 97, 2818-2826. http://dx.doi.org/10.1210/jc.2012-1205

[34] Derosa, G., Carbone, A., Franzetti, I., Querci, F., Fogari, E., Bianchi, L., Bonaventura, A., Romano, D., Cicero, A.F. and Maffioli, P. (2012) Effects of a Combination of Sitagliptin plus Metformin vs. Metformin Monotherapy on Glycemic Control, $\beta$-Cell Function and Insulin Resistance in Type 2 Diabetic Patients. Diabetes Research and Clinical Practice, 98, 51-60. http://dx.doi.org/10.1016/j.diabres.2012.05.022

[35] Kim, H.S., Shin, J.A., Lee, S.H., Kim, E.S., Cho, J.H., Son, H.Y. and Yoon, K.H. (2013) A Comparative Study of the Effects of a Dipeptidyl Peptidase-IV Inhibitor and Sulfonylurea on Glucose Variability in Patients with Type 2 Diabetes with Inadequate Glycemic Control on Metformin. Diabetes Technology \& Therapeutics, 15, 810-816. http://dx.doi.org/10.1089/dia.2013.0038

[36] Solis-Herrera, C., Triplitt, C., Garduno-Garcia, J. de J., Adams, J., DeFronzo, R.A. and Cersosimo, E. (2013) Mechanisms of Glucose Lowering of Dipeptidyl Peptidase-4 Inhibitor Sitagliptin When Used Alone or with Metformin in Type 2 Diabetes: A Double-Tracer Study. Diabetes Care, 36, 2756-2762. http://dx.doi.org/10.2337/dc12-2072

[37] Vardarli, I., Arndt, E., Deacon, C.F., Holst, J.J. and Nauck, M.A. (2014) Effects of Sitagliptin and Metformin Treatment on Incretin Hormone and Insulin Secretory Responses to Oral and "Isoglycemic" Intravenous Glucose. Diabetes, 63, 663-674. http://dx.doi.org/10.2337/db13-0805

[38] Sjöstrand, M., Iqbal, N., Lu, J. and Hirshberg, B. (2014) Saxagliptin Improves Glycemic Control by Modulating Postprandial Glucagon and C-Peptide Levels in Chinese Patients with Type 2 Diabetes. Diabetes Research and Clinical Practice, 105, 185-191. http://dx.doi.org/10.1016/j.diabres.2014.05.006

[39] Zhang, Y., Chi, J., Wang, W., Hong, J., Gu, W., Wang, B. and Ning, G. (2015) Different Effects of Two Dipeptidyl Peptidase-4 Inhibitors and Glimepiride on $\beta$-Cell Function in a Newly Designed Two-Step Hyperglycemic Clamp. Journal of Diabetes, 7, 213-221. http://dx.doi.org/10.1111/1753-0407.12175

[40] Schernthaner, G., Durán-Garcia, S., Hanefeld, M., Langslet, G., Niskanen, L., Östgren, C.J., Malvolti, E. and Hardy, E. (2015) Efficacy and Tolerability of Saxagliptin Compared with Glimepiride in Elderly Patients with Type 2 Diabetes: A Randomized, Controlled Study (GENERATION). Diabetes, Obesity and Metabolism, 17, 630-638. http://dx.doi.org/10.1111/dom.12461

[41] Gudipaty, L., Rosenfeld, N.K., Fuller, C.S., Gallop, R., Schutta, M.H. and Rickels, M.R. (2014) Effect of Exenatide, Sitagliptin, or Glimepiride on $\beta$-Cell Secretory Capacity in Early Type 2 Diabetes. Diabetes Care, 37, 2451-2458. http://dx.doi.org/10.2337/dc14-0398

[42] Schade, D.S., Eaton, R.P., Mitchell, W. and Ortega, T. (1980) Glucose and Insulin Response to High Carbohydrate Meals in Normal and Maturity-Onset Diabetic Subjects. Diabetes Care, 3, 242-244.

http://dx.doi.org/10.2337/diacare.3.2.242

[43] Ahrén, B., Johnson, S.L., Stewart, M., Cirkel, D.T., Yang, F., Perry, C. and Feinglos, M.N., HARMONY 3 Study Group (2014) HARMONY 3: 104-Week Randomized, Double-Blind, Placebo- and Active-Controlled Trial Assessing the Efficacy and Safety of Albiglutide Compared with Placebo, Sitagliptin, and Glimepiride in Patients with Type 2 Diabetes Taking Metformin. Diabetes Care, 37, 2141-2148. http://dx.doi.org/10.2337/dc14-0024

[44] Cefalu, W.T., Leiter, L.A., Yoon, K.H., Arias, P., Niskanen, L., Xie, J., Balis, D.A., Canovatchel, W. and Meininger, G. (2013) Efficacy and Safety of Canagliflozin versus Glimepiride in Patients with Type 2 Diabetes Inadequately Controlled with Metformin (CANTATA-SU): 52 Week Results from a Randomised, Double-Blind, Phase 3 Non-Inferiority Trial. The Lancet, 382, 941-950. http://dx.doi.org/10.1016/S0140-6736(13)60683-2 
[45] Ridderstråle, M., Andersen, K.R., Zeller, C., Kim, G., Woerle, H.J. and Broedl, U.C. (2014) EMPA-REG H2H-SU Trial Investigators Comparison of Empagliflozin and Glimepiride as Add-On to Metformin in Patients with Type 2 Diabetes: A 104-Week Randomised, Active-Controlled, Double-Blind, Phase 3 Trial. The Lancet Diabetes \& Endocrinology, 2, 691-700. http://dx.doi.org/10.1016/S2213-8587(14)70120-2

[46] Saulsberry, W.J., Coleman, C.I., Mearns, E.S., Zaccaro, E., Doleh, Y. and Sobieraj, D.M. (2015) Comparative Efficacy and Safety of Antidiabetic Drug Regimens Added to Stable and Inadequate Metformin and Thiazolidinedione Therapy in Type 2 Diabetes. International Journal of Clinical Practice, In Press. http://dx.doi.org/10.1111/ijcp.12698

[47] Holleman, F., Uijldert, M., Donswijk, L.F. and Gale, E.A. (2015) Productivity of Authors in the Field of Diabetes: Bibliographic Analysis of Trial Publications. BMJ, 351, h2638. http://dx.doi.org/10.1136/bmj.h2638

[48] Wager, E. (2015) Are Prolific Authors Too Much of a Good Thing? BMJ, 351, h2782. http://dx.doi.org/10.1136/bmj.h2782

[49] Nathan, D.M., Buse, J.B., Kahn, S.E., Krause-Steinrauf, H., Larkin, M.E., Staten, M., Wexler, D. and Lachin, J.M., GRADE Study Research Group (2013) Rationale and Design of the Glycemia Reduction Approaches in Diabetes: A Comparative Effectiveness Study (GRADE). Diabetes Care, 36, 2254-2261. http://dx.doi.org/10.2337/dc13-0356

[50] Simpson, S.H., Majumdar, S.R., Tsuyuki, R.T., Eurich, D.T. and Johnson, J.A. (2006) Dose-Response Relation between Sulfonylurea Drugs and Mortality in Type 2 Diabetes Mellitus: A Population-Based Cohort Study. Canadian Medical Association Journal, 174, 169-174. http://dx.doi.org/10.1503/cmaj.050748

[51] Tzoulaki, I., Molokhia, M., Curcin, V., Little, M.P., Millett, C.J., Ng, A., Hughes, R.I., Khunti, K., Wilkins, M.R., Majeed, A. and Elliott, P. (2009) Risk of Cardiovascular Disease and All Cause Mortality among Patients with Type 2 Diabetes Prescribed Oral Antidiabetes Drugs: Retrospective Cohort Study Using UK General Practice Research Database. BMJ, 339, b4731. http://dx.doi.org/10.1136/bmj.b4731

[52] Morgan, C.L., Poole, C.D., Evans, M., Barnett, A.H., Jenkins-Jones, S. and Currie, C.J. (2012) What Next after Metformin? A Retrospective Evaluation of the Outcome of Second-Line, Glucose-Lowering Therapies in People with Type 2 Diabetes. The Journal of Clinical Endocrinology \& Metabolism, 97, 4605-4612. http://dx.doi.org/10.1210/jc.2012-3034

[53] Morgan, C.L., Mukherjee, J., Jenkins-Jones, S., Holden, S.E. and Currie, C.J. (2014) Association between First-Line Monotherapy with Sulphonylurea versus Metformin and Risk of All-Cause Mortality and Cardiovascular Events: A Retrospective, Observational Study. Diabetes, Obesity and Metabolism, 16, 957-962. http://dx.doi.org/10.1111/dom.12302

[54] Gangji, A.S., Cukierman, T., Gerstein, H.C., Goldsmith, C.H. and Clase, C.M.A. (2007) Systematic Review and MetaAnalysis of Hypoglycemia and Cardiovascular Events: A Comparison of Glyburide with Other Secretagogues and with Insulin. Diabetes Care, 30, 389-394. http://dx.doi.org/10.2337/dc06-1789

[55] ADVANCE Collaborative Group, Patel, A., MacMahon, S., Chalmers, J., Neal, B., Billot, L., Woodward, M., Marre, M., Cooper, M., Glasziou, P., Grobbee, D., Hamet, P., Harrap, S., Heller, S., Liu, L., Mancia, G., Mogensen, C.E., Pan, C., Poulter, N., Rodgers, A., Williams, B. and Bompoint, S. (2008) Intensive Blood Glucose Control and Vascular Outcomes in Patients with Type 2 Diabetes. New England Journal of Medicine, 358, 2560-2572. http://dx.doi.org/10.1056/NEJMoa0802987

[56] Holman, R.R., Paul, S.K., Bethel, M.A., Matthews, D.R. and Neil, H.A. (2008) 10-Year Follow-Up of Intensive Glucose Control in Type 2 Diabetes. New England Journal of Medicine, 359, 1577-1589. http://dx.doi.org/10.1056/NEJMoa0806470

[57] Poulter, N.R. (2009) Blood Pressure and Glucose Control in Subjects with Diabetes: New Analyses from ADVANCE. Journal of Hypertension, 27, S3-S8. http://dx.doi.org/10.1097/01.hjh.0000354417.70192.be

[58] BARI 2D Study Group, Frye, R.L., August, P., Brooks, M.M., Hardison, R.M., Kelsey, S.F., MacGregor, J.M., Orchard, T.J., Chaitman, B.R., Genuth, S.M., Goldberg, S.H., Hlatky, M.A., Jones, T.L., Molitch, M.E., Nesto, R.W., Sako, E.Y. and Sobel, B.E. (2009) A Randomized Trial of Therapies for Type 2 Diabetes and Coronary Artery Disease. New England Journal of Medicine, 360, 2503-2515. http://dx.doi.org/10.1056/NEJMoa0805796

[59] Roumie, C.L., Hung, A.M., Greevy, R.A., Grijalva, C.G., Liu, X., Murff, H.J., Elasy, T.A. and Griffin, M.R. (2012) Comparative Effectiveness of Sulfonylurea and Metformin Monotherapy on Cardiovascular Events in Type 2 Diabetes Mellitus: A Cohort Study. Annals of Internal Medicine, 157, 601-610. http://dx.doi.org/10.7326/0003-4819-157-9-201211060-00003

[60] Hung, Y.C., Lin, C.C., Wang, T.Y., Chang, M.P., Sung, F.C. and Chen, C.C. (2013) Oral Hypoglycaemic Agents and the Development of Non-Fatal Cardiovascular Events in Patients with Type 2 Diabetes Mellitus. Diabetes/Metabolism Research and Reviews, 29, 673-679. http://dx.doi.org/10.1002/dmrr.2444

[61] Simpson, S.H., Lee, J., Choi, S., Vandermeer, B., Abdelmoneim, A.S. and Featherstone, T.R. (2015) Mortality Risk among Sulfonylureas: A Review and Network Meta-Analysis. The Lancet Diabetes \& Endocrinology, 3, 43-51. http://dx.doi.org/10.1016/S2213-8587(14)70213-X 
[62] Floyd, J.S., Wiggins, K.L., Sitlani, C.M., Flory, J.H., Dublin, S., Smith, N.L., Heckbert, S.R. and Psaty, B.M. (2015) Case-Control Study of Second-Line Therapies for Type 2 Diabetes in Combination with Metformin and the Comparative Risks of Myocardial Infarction and Stroke. Diabetes, Obesity and Metabolism. (Epub ahead of Print) http://dx.doi.org/10.1111/dom.12537

[63] Sadikot, S.M. and Mogensen, C.E. (2008) Risk of Coronary Artery Disease Associated with Initial Sulphonylurea Treatment of Patients with Type 2 Diabetes: A Matched Case-Control Study. Diabetes Research and Clinical Practice, 82, 391-395. http://dx.doi.org/10.1016/j.diabres.2008.09.004

[64] Pantalone, K.M., Kattan, M.W., Yu, C., Wells, B.J., Arrigain, S., Jain, A., Atreja, A. and Zimmerman, R.S. (2010) The Risk of Overall Mortality in Patients with Type 2 Diabetes Receiving Glipizide, Glyburide, or Glimepiride Monotherapy: A Retrospective Analysis. Diabetes Care, 33, 1224-1229. http://dx.doi.org/10.2337/dc10-0017

[65] Pantalone, K.M., Kattan, M.W., Yu, C., Wells, B.J., Arrigain, S., Jain, A., Atreja, A. and Zimmerman, R.S. (2012) Increase in Overall Mortality Risk in Patients with Type 2 Diabetes Receiving Glipizide, Glyburide or Glimepiride Monotherapy versus Metformin: A Retrospective Analysis. Diabetes, Obesity and Metabolism, 14, 803-809. http://dx.doi.org/10.1111/j.1463-1326.2012.01604.x

[66] Onuma, H., Inukai, K., Watanabe, M., Sumitani, Y., Hosaka, T. and Ishida, H. (2014) Effects of Long-Term Monotherapy with Glimepiride vs. Glibenclamide on Glycemic Control and Macrovascular Events in Japanese Type 2 Diabetic Patients. Japanese Domestic Market, 4, 33-37.

[67] Reshma, E. and Udaya, K. (2015) Improvement in Cardiovascular Risk Markers with Glimepiride in Non Obese Subjects with Prediabetes. Abstract Presented at Annual Meeting, Endocrine Society, Washington DC.

[68] Kabadi, U.M. and Kabadi, M.U. (2001) Improvement in Lipids with Glimepiride in Type 2 Diabetes Mellitus. Diabetes Research, 35, 155.

[69] Siluk, D., Kaliszan, R., Haber, P., Petrusewicz, J., Brzozowski, Z. and Sut, G. (2002) Antiaggregatory Activity of Hypoglycaemic Sulphonylureas. Diabetologia, 45, 1034-1037. http://dx.doi.org/10.1007/s00125-002-0855-0

[70] Derosa, G., Mugellini, A., Ciccarelli, L., Crescenzi, G. and Fogari, R. (2003) Comparison between Repaglinide and Glimepiride in Patients with Type 2 Diabetes Mellitus: A One-Year, Randomized, Double-Blind Assessment of Metabolic Parameters and Cardiovascular Risk Factors. Clinical Therapeutics, 25, 472-478. http://dx.doi.org/10.1016/S0149-2918(03)80090-5

[71] Derosa, G., Franzetti, I., Gadaleta, G., Ciccarelli, L. and Fogari, R. (2004) Metabolic Variations with Oral Antidiabetic Drugs in Patients with Type 2 Diabetes: Comparison between Glimepiride and Metformin. Diabetes, Nutrition \& Metabolism, 17, 143-150.

[72] Derosa, G., Gaddi, A.V., Ciccarelli, L., Fogari, E., Ghelfi, M., Ferrari, I. and Cicero, A.F. (2005) Long-Term Effect of Glimepiride and Rosiglitazone on Non-Conventional Cardiovascular Risk Factors in Metformin-Treated Patients Affected by Metabolic Syndrome: A Randomized, Double-Blind Clinical Trial. Journal of International Medical Research, 33, 284-294. http://dx.doi.org/10.1177/147323000503300303

[73] Koshiba, K., Nomura, M., Nakaya, Y. and Ito, S. (2006) Efficacy of Glimepiride on Insulin Resistance, Adipocytokines, and Atherosclerosis. The Journal of Medical Investigation, 53, 87-94. http://dx.doi.org/10.2152/jmi.53.87

[74] Xu, D.Y., Zhao, S.P., Huang, Q.X., Du, W., Liu, Y.H., Liu, L. and Xie, X.M. (2010) Effects of Glimepiride on Metabolic Parameters and Cardiovascular Risk Factors in Patients with Newly Diagnosed Type 2 Diabetes Mellitus. Diabetes Research and Clinical Practice, 88, 71-75. http://dx.doi.org/10.1016/j.diabres.2009.12.010

[75] Nakamura, I., Oyama, J., Komoda, H., Shiraki, A., Sakamoto, Y., Taguchi, I., Hiwatashi, A., Komatsu, A., Takeuchi, M., Yamagishi, S., Inoue, T. and Node, K. (2014) Possible Effects of Glimepiride beyond Glycemic Control in Patients with Type 2 Diabetes: A Preliminary Report. Cardiovascular Diabetology, 13, 15. http://dx.doi.org/10.1186/1475-2840-13-15

[76] Green, J.B., Bethel, M.A., Armstrong, P.W., Buse, J.B., Engel, S.S., Garg, J., Josse, R., Kaufman, K.D., Koglin, J., Korn, S., Lachin, J.M., McGuire, D.K., Pencina, M.J., Standl, E., Stein, P.P., Suryawanshi, S., Van de Werf, F., Peterson, E.D. and Holman, R.R., TECOS Study Group (2015) Effect of Sitagliptin on Cardiovascular Outcomes in Type 2 Diabetes. New England Journal of Medicine, 373, 232-242. http://dx.doi.org/10.1056/NEJMoa1501352

[77] Leiter, L.A., Teoh, H., Braunwald, E., Mosenzon, O., Cahn, A., Kumar, K.M., Smahelova, A., Hirshberg, B., Stahre, C., Frederich, R., Bonnici, F., Scirica, B.M., Bhatt, D.L. and Raz, I. (2015) SAVOR-TIMI 53 Steering Committee and Investigators Efficacy and Safety of Saxagliptin in Older Participants in the SAVOR-TIMI 53 Trial. Diabetes Care, 38, 1145-1153. http://dx.doi.org/10.2337/dc14-2868

[78] Rosenstock, J., Marx, N., Neubacher, D., Seck, T., Patel, S., Woerle, H.J. and Johansen, O.E. (2015) Cardiovascular Safety of Linagliptin in Type 2 Diabetes: A Comprehensive Patient-Level Pooled Analysis of Prospectively Adjudicated Cardiovascular Events. Cardiovascular Diabetology, 14, 57. http://dx.doi.org/10.1186/s12933-015-0215-2

[79] Fisher, M., Petrie, M.C., Ambery, P.D., Donaldson, J., McMurray, J.J. and Ye, J. (2015) Cardiovascular Safety of Al- 
biglutide in the Harmony Programme: A Meta-Analysis. The Lancet Diabetes \& Endocrinology, 3, 697-703. http://dx.doi.org/10.1016/S2213-8587(15)00233-8

[80] Paul, S.K., Klein, K., Maggs, D. and Best, J.H. (2015) The Association of the Treatment with Glucagon-Like Peptide-1 Receptor Agonist Exenatide or Insulin with Cardiovascular Outcomes in Patients with Type 2 Diabetes: A Retrospective Observational Study. Cardiovascular Diabetology, 14, 10. http://dx.doi.org/10.1186/s12933-015-0178-3

[81] Monami, M., Dicembrini, I., Nardini, C., Fiordelli, I. and Mannucci, E. (2014) Effects of Glucagon-Like Peptide-1 Receptor Agonists on Cardiovascularrisk: A Meta-Analysis of Randomized Clinical Trials. Diabetes, Obesity and Metabolism, 16, 38-47. http://dx.doi.org/10.1111/dom.12175

[82] Sun, F., Yu, K., Wu, S., Zhang, Y., Yang, Z., Shi, L., Ji, L. and Zhan, S. (2012) Cardiovascular Safety and Glycemic Control of Glucagon-Like Peptide-1 Receptor Agonists for Type 2 Diabetes Mellitus: A Pairwise and Network Meta-Analysis. Diabetes Research and Clinical Practice, 98, 386-395. http://dx.doi.org/10.1016/j.diabres.2012.09.004

[83] Ratner, R., Han, J., Nicewarner, D., Yushmanova, I., Hoogwerf, B.J. and Shen, L. (2011) Cardiovascular Safety of Exenatide BID: An Integrated Analysis from Controlled Clinical Trials in Participants with Type 2 Diabetes. Cardiovascular Diabetology, 10, 22. http://dx.doi.org/10.1186/1475-2840-10-22

[84] Cefalu, W.T., Leiter, L.A., de Bruin, T.W., Gause-Nilsson, I. and Sugg, J. (2015) Dapagliflozin's Effects on Glycemia and Cardiovascular Risk Factors in High-Risk Patients with Type 2 Diabetes: A 24-Week, Multicenter, Randomized, Double-Blind, Placebo-Controlled Study with a 28-Week Extension. Diabetes Care, 38, 1218-1227. http://dx.doi.org/10.2337/dc14-0315

[85] Kabadi, U.M. (1995) Combination Sulfonylurea and Insulin Therapy in Diabetes Mellitus. Comprehensive Therapy, 21, 731-736.

[86] Johnson, J.L., Wolf, S.L. and Kabadi, U.M. (1996) Efficacy of Insulin and Sulfonylurea Combination Therapy in Type II Diabetes. A Meta-Analysis of the Randomized Placebo-Controlled Trials. Archives of Internal Medicine, 156, 259264. http://dx.doi.org/10.1001/archinte.1996.00440030049007

[87] Kabadi, M.U. and Kabadi, U.M. (2003) Efficacy of Sulfonylureas with Insulin in Type 2 Diabetes Mellitus. The Annals of Pharmacotherapy, 37, 1572-1576. http://dx.doi.org/10.1345/aph.1C492

[88] Bell, D.S. and Yumuk, V. (1997) Frequency of Severe Hypoglycemia in Patients with Noninsulin-Dependent Diabetes Mellitus Treated with Sulfonylureas or Insulin. Endocrine Practice, 3, 281-283. http://dx.doi.org/10.4158/EP.3.5.281

[89] Kahn, S.E., Haffner, S.M., Heise, M.A., Herman, W.H., Holman, R.R., Jones, N.P., Kravitz, B.G., Lachin, J.M., O’Neill, M.C., Zinman, B. and Viberti, G., ADOPT Study Group (2006) Glycemic Durability of Rosiglitazone, Metformin, or Glyburide Monotherapy. New England Journal of Medicine, 355, 2427-2443. http://dx.doi.org/10.1056/NEJMoa066224

[90] Dills, D.G. and Schneider, J., Glimepiride/Glyburide Research Group (1996) Clinical Evaluation of Glimepiride versus Glyburide in NIDDM in a Double-Blind Comparative Study. Hormone and Metabolic Research, 28, 426-429. http://dx.doi.org/10.1055/s-2007-979831

[91] Holstein, A., Plaschke, A. and Egberts, E.H. (2001) Lower Incidence of Severe Hypoglycaemia in Patients with Type 2 Diabetes Treated with Glimepiride versus Glibenclamide. Diabetes/Metabolism Research and Reviews, 17, 467-473. http://dx.doi.org/10.1002/dmrr.235

[92] Kaur, A. and Winters, S.J. (2015) Severe Hypercalcemia and Hypernatremia in a Patient Treated with Canagliflozin. Endocrinology, Diabetes \& Metabolism Case Reports, 2015, Article ID: 150042.

[93] Lighten, Y., Škrtić, M., Yang, G.K., Yip, P.M., Perkins, B.A. and Cherney, D.Z. (2015) Glycosuria-Mediated Urinary Uric Acid Excretion in Patients with Uncomplicated Type 1 Diabetes Mellitus. AJP: Renal Physiology, 308, F77-F83. http://dx.doi.org/10.1152/ajprenal.00555.2014

[94] Taylor, S.I., Blau, J.E. and Rother, K.I. (2015) Possible Adverse Effects of SGLT2 Inhibitors on Bone. The Lancet Diabetes \& Endocrinology, 3, 8-10. http://dx.doi.org/10.1016/S2213-8587(14)70227-X

[95] US Food and Drug Administration Drug Safety Communication (2015) FDA Warns That SGLT2 Inhibitors for Diabetes May Resulting a Serious Condition of Too Much Acid in Blood. http://www.fda.gov/downloads/Drugs/DrugSafety/UCM446954.pdf

[96] European Medicine Agency (2015) Review of Diabetes Medicines Called SGLT2 Inhibitors Started: Risk of Diabetic Ketoacidosis to Be Examined. http://www.ema.europa.eu/docs/en document/SGLT2 inhibitors 20/procedure started/WC5001879826.pdf

[97] Sargent, J. (2015) Therapy: SGLT2 Inhibitor Dapagliflozin Promotes Glucagon Secretion in $\alpha$ Islet Cells. Nature Reviews Endocrinology, 11, 382. http://dx.doi.org/10.1038/nrendo.2015.70

[98] Kaku, K., Watada, H., Iwamoto, Y., Utsunomiya, K., Terauchi, Y., Tobe, K., Tanizawa, Y., Araki, E., Ueda, M., Suganami, H. and Watanabe, D., Tofogliflozin 003 Study Group (2014) Efficacy and Safety of Monotherapy with the Novel Sodium/Glucose Cotransporter-2 Inhibitor Tofogliflozin in Japanese Patients with Type 2 Diabetes Mellitus: A 
Combined Phase 2 and 3 Randomized, Placebo-Controlled, Double-Blind, Parallel-Group Comparative Study. Cardiovascular Diabetology, 13, 65-104. http://dx.doi.org/10.1186/1475-2840-13-65

[99] Peters, A.L., Buschur, E., Buse, J.B., Cohan, P., Diner, J.C. and Hirsch, I. (2015) Euglycemic Diabetic Ketoacidosis: A Potential Complication of Treatment with Sodium-Glucose Cotransporter 2 Inhibition. Diabetes Care, 38, 1687-1693. http://dx.doi.org/10.2337/dc15-0843

[100] Verma, R. (2014) Canagliflozin Associated Acute Pancreatitis. American Journal of Therapeutics. (Epub ahead of Print)

[101] Chowdhary, M., Kabbani, A.A. and Chhabra, A. (2015) Canagliflozin-Induced Pancreatitis: A Rare Side Effect of a New Drug. Therapeutics and Clinical Risk Management, 11, 991-994. http://dx.doi.org/10.2147/TCRM.S86641

[102] Srivali, N., Thongprayoon, C., Cheungpasitporn, W. and Ungprasert, P. (2015) Acute Pancreatitis in the Use of Canagliflozin: A Rare Side-Effect of the Novel Therapy for Type 2 Diabetes Mellitus. Journal of Basic and Clinical Pharmacy, 6, 101-102. http://dx.doi.org/10.4103/0976-0105.160753

[103] Kabadi, U.M. (1994) Pancreatic Ketoacidosis: Imitator of Diabetic Ketoacidosis. International Journal of Diabetes in Developing Countries, 14, 74-82.

[104] Kabadi, U.M. (1995) Pancreatic Ketoacidosis: Ketonemia Associated with Acute Pancreatitis. Postgraduate Medical Journal, 71, 32-35. http://dx.doi.org/10.1136/pgmj.71.831.32

[105] Kabadi, U.M. (1999) Pancreatic Ketoacidosis: Secondary to Increased Circulating Lipase of Acute Pancreatitis. Diabetes Research, 34, 1-7.

[106] Kabadi, U.M. (2015) Pancreatic Ketoacidosis (Kabadi Syndrome) Mimicking Diabetic Ketocidosis. Endocrine Practice, 21, 1-2.

[107] Kalra, S., Sahay, R. and Gupta, Y. (2015) Sodium Glucose Transporter 2 (SGLT2) Inhibition and Ketogenesis. Indian Journal of Endocrinology and Metabolism, 19, 524-528. http://dx.doi.org/10.4103/2230-8210.157859

[108] No Authors Listed (2015) In Brief: Ketoacidosis with SGLT2 Inhibitors. Medical Letter on Drugs and Therapeutics, 57, 94.

[109] Taylor, S.I., Blau, J.E. and Rother, K.I. (2015) SGLT2 Inhibitors May Predispose to Ketoacidosis. The Journal of Clinical Endocrinology \& Metabolism, 100, 2849-2852. http://dx.doi.org/10.1210/jc.2015-1884

[110] Rosenstock, J. and Ferrannini, E. (2015) Euglycemic Diabetic Ketoacidosis: A Predictable, Detectable, and Preventable Safety Concern with SGLT2 Inhibitors. Diabetes Care, 38, 1638-1642. http://dx.doi.org/10.2337/dc15-1380

[111] Erondu, N., Desai, M., Ways, K. and Meininger, G. (2015) Diabetic Ketoacidosis and Related Events in the Canagliflozin Type 2 Diabetes Clinical Program. Diabetes Care, 38, 1680-1686. http://dx.doi.org/10.2337/dc15-1251

[112] Foushee, J.A., Goodbar, N.H., Kelly, J.L. and Clarke, S.L. (2014) Cerebrovascular Accident in a High-Risk Patient During the Early Initiation Phase With Canagliflozin. Annals of Pharmacotherapy, 48, 1066-1069.

http://dx.doi.org/10.1177/1060028014529412

[113] Hinnen, D. (2015) Glucuretic Effects and Renal Safety of Dapagliflozin in Patients with Type 2 Diabetes. Therapeutic Advances in Endocrinology and Metabolism, 6, 92-102. http://dx.doi.org/10.1177/2042018815575273

[114] Vivian, E.M. (2015) Dapagliflozin: A New Sodium-Glucose Cotransporter 2 Inhibitor for Treatment of Type 2 Diabetes. American Journal of Health-System Pharmacy, 72, 361-372. http://dx.doi.org/10.2146/ajhp140168

[115] Lin, H.W. and Tseng, C.H. (2014) A Review on the Relationship between SGLT2 Inhibitors and Cancer. International Journal of Endocrinology, 2014, Article ID: 719578. http://dx.doi.org/10.1155/2014/719578

[116] UK Prospective Diabetes Study Group (1995) UK Prospective Diabetes Study 16: Overview of 6 Years' Therapy of Type II Diabetes: A Progressive Disease. Diabetes, 44, 1249-1258. http://dx.doi.org/10.2337/diab.44.11.1249

[117] Jain, R., Kabadi, U. and Kabadi, M. (2008) Is Beta-Cell Failure in Type 2 Diabetes Mellitus Reversible? International Journal of Diabetes in Developing Countries, 28, 1-5. http://dx.doi.org/10.4103/0973-3930.41978

[118] Torquati, A., Lutfi, R., Abumrad, N. and Richards, W.O. (2005) Is Roux-en-Y Gastric Bypass Surgery the Most Effective Treatment for Type 2 Diabetes Mellitus in Morbidly Obese Patients? Journal of Gastrointestinal Surgery, 9, 11121116.

[119] Alexandrides, T.K., Skroubis, G. and Kalfarentzos, F. (2007) Resolution of Diabetes Mellitus and Metabolic Syndrome Following Roux-en-Y Gastric Bypass and a Variant of Biliopancreatic Diversion in Patients with Morbid Obesity. $O b-$ esity Surgery, 17, 176-184. http://dx.doi.org/10.1007/s11695-007-9044-Z

[120] Ribaric, G., Buchwald, J.N. and McGlennon, T.W. (2014) Diabetes and Weight in Comparative Studies of Bariatric Surgery vs. Conventional Medical Therapy: A Systematic Review and Meta-Analysis. Obesity Surgery, 24, 437-455. http://dx.doi.org/10.1007/s11695-013-1160-3 
[121] Gloy, V.L., Briel, M., Bhatt, D.L., Kashyap, S.R., Schauer, P.R., Mingrone, G., Bucher, H.C. and Nordmann, A.J. (2013) Bariatric Surgery versus Non-Surgical Treatment for Obesity: A Systematic Review and Meta-Analysis of Randomised Controlled Trials. BMJ, 347, f5934-f5972. http://dx.doi.org/10.1136/bmj.f5934

[122] Castagneto-Gissey, L. and Mingrone, G. (2012) Insulin Sensitivity and Secretion Modifications after Bariatric Surgery. Journal of Endocrinological Investigation, 35, 692-698.

[123] Merlotti, C., Morabito, A. and Pontiroli, A.E. (2014) Prevention of Type 2 Diabetes: A Systematic Review and Meta-Analysis of Different Intervention Strategies. Diabetes, Obesity and Metabolism, 16, 719-727. http://dx.doi.org/10.1111/dom.12270

[124] Quan, Y., Huang, A., Ye, M., Xu, M., Zhuang, B., Zhang, P., Yu, B. and Min, Z. (2015) Efficacy of Laparoscopic Mini Gastric Bypass for Obesity and Type 2 Diabetes Mellitus: A Systematic Review and Meta-Analysis. Gastroenterology Research and Practice, 2015, Article ID: 152852. http://dx.doi.org/10.1155/2015/152852

[125] Hayden, M.R. (2007) Islet Amyloid and Fibrosis in the Cardiometabolic Syndrome and Type 2 Diabetes Mellitus. Journal of the Cardiometabolic Syndrome, 2, 70-75. http://dx.doi.org/10.1111/j.1559-4564.2007.06159.x

[126] Kabadi, U., Kabadi, M.U., Weber, S., Bubolz, A. and Finnerty, E. (2015) Progressive $\beta$-Cell Failure in Type 2 Diabetes Mellitus: Microvascular Pancreatic Isletopathy? Journal of Diabetes Mellitus, 5, 21-27.

http://dx.doi.org/10.4236/jdm.2015.51003

[127] ORIGIN Trial Investigators, Gerstein, H.C., Bosch, J., Dagenais, G.R., Díaz, R., Jung, H., Maggioni, A.P., Pogue, J., Probstfield, J., Ramachandran, A., Riddle, M.C., Rydén, L.E. and Yusuf, S. (2012) Basal Insulin and Cardiovascular and Other Outcomes in Dysglycemia. New England Journal of Medicine, 367, 319-328. http://dx.doi.org/10.1056/NEJMoa1203858

[128] Cukierman-Yaffe, T., Bosch, J., Diaz, R., Dyal, L., Hancu, N., Hildebrandt, P., Lanas, F., Lewis, B.S., Marre, M., Yale, J.F., Yusuf, S. and Gerstein, H.C., ORIGIN Investigators (2014) Effects of Basal Insulin Glargine and Omega-3 Fatty Acid on Cognitive Decline and Probable Cognitive Impairment in People with Dysglycaemia: A Substudy of the ORIGIN Trial. The Lancet Diabetes \& Endocrinology, 2, 562-572. http://dx.doi.org/10.1016/S2213-8587(14)70062-2

[129] Kabadi, U.M. (2013) Comparative Efficacy between Glimepiride and Metformin in Preventing Progression of Prediabetes to Type 2 Diabetes. Journal of Diabetes Mellitus, 3, 129-133. http://dx.doi.org/10.4236/jdm.2013.33019

[130] Kabadi, U.M. (2015) Major Pathophysiologic Factor in Pre-Diabetes and Type 2 Diabetes Mellitus: Decreased Insulin Secretion in Lean and Insulin Resistance in Obese Subjects. Annual Meeting Abstract No. 2851, American Diabetes Association, Alexandria, VA.

[131] Riddle, M.E. and Schneider, J., The Glimepiride Combination Group (1998) Beginning Insulin Treatment of Obese Patient with Evening 70/30 Insulin plus Glimepiride versus Insulin Alone. Diabetes Care, 21, 1052-1057. http://dx.doi.org/10.2337/diacare.21.7.1052

[132] Raskin, P., Rendell, M., Riddle, M.C., Dole, J.F., Freed, M.I. and Rosenstock, J., Rosiglitazone Clinical Trials Study Group (2001) A Randomized Trial of Rosiglitazone Therapy in Patients with Inadequately Controlled Insulin-Treated Type 2 Diabetes. Diabetes Care, 24, 1226-1232. http://dx.doi.org/10.2337/diacare.24.7.1226

[133] Rosenstock, J., Einhorn, D., Hershon, K., Glazer, N.B. and Yu, S., Pioglitazone 014 Study Group (2002) Efficacy and Safety of Pioglitazone in Type 2 Diabetes: A Randomised, Placebo-Controlled Study in Patients Receiving Stable Insulin Therapy. International Journal of Clinical Practice, 56, 251-257.

[134] Fritsche, A., Schweitzer, M.A. and Häring, H.U., 4001 Study Group (2003) Glimepiride Combined with Morning Insulin Glargine, Bedtime Neutral Protamine Hagedorn Insulin, or Bedtime Insulin Glargine in Patients with Type 2 Diabetes: A Randomized, Controlled Trial. Annals of Internal Medicine, 138, 952-959. http://dx.doi.org/10.7326/0003-4819-138-12-200306170-00006

[135] Janka, H.U., Plewe, G., Riddle, M.C., Kliebe-Frisch, C., Schweitzer, M.A. and Yki-Järvinen, H. (2005) Comparison of Basal Insulin Added to Oral Agents versus Twice-Daily Premixed Insulin as Initial Insulin Therapy for Type 2 Diabetes. Diabetes Care, 28, 254-259. http://dx.doi.org/10.2337/diacare.28.2.254

[136] Standl, E., Maxeiner, S., Raptis, S., Karimi-Anderesi, Z. and Schweitzer, M.A., HOE901/4009 Study Group (2005) Good Glycemic Control with Flexibility in Timing of Basal Insulin Supply: A 24-Week Comparison of Insulin Glargine Given Once Daily in the Morning or at Bedtime in Combination with Morning Glimepiride. Diabetes Care, 28, 419-420. http://dx.doi.org/10.2337/diacare.28.2.419

[137] Eliaschewitz, F.G., Calvo, C., Valbuena, H., Ruiz, M., Aschner, P., Villena, J., Ramirez, L.A. and Jimenez, J., HOE 901/4013 LA Study Group (2006) Therapy in Type 2 Diabetes: Insulin Glargine vs. NPH Insulin Both in Combination with Glimepiride. Archives of Medical Research, 37, 495-501. http://dx.doi.org/10.1016/j.arcmed.2005.10.015

[138] Kabadi, U.M. (2006) Comparative Efficacy of Glimepiride and/or Metformin with Insulin in Type 2 Diabetes. Diabetes Research \& Clinical Practice, 72, 265-270. http://dx.doi.org/10.1016/j.diabres.2005.10.024

[139] Janka, H.U., Plewe, G. and Busch, K. (2007) Combination of Oral Antidiabetic Agents with Basal Insulin versus Pre- 
mixed Insulin Alone in Randomized Elderly Patients with Type 2 Diabetes Mellitus. Journal of the American Geriatrics Society, 55, 182-188. http://dx.doi.org/10.1111/j.1532-5415.2007.01043.x

[140] Pan, C.Y., Sinnassamy, P., Chung, K.D. and Kim, K.W., LEAD Study Investigators Group (2007) Insulin Glargine versus NPH Insulin Therapy in Asian Type 2 Diabetes Patients. Diabetes Research and Clinical Practice, 76, 111-118. http://dx.doi.org/10.1016/j.diabres.2006.08.012

[141] Schiel, R. and Müller, U.A. (2008) Efficacy and Treatment Satisfaction of Once-Daily Insulin Glargine plus One or Two Oral Antidiabetic Agents versus Continuing Premixed Human Insulin in Patients with Type 2 Diabetes Previously on Long-Term Conventional Insulin Therapy: The SWITCH Pilot Study. Experimental and Clinical Endocrinology \& Diabetes, 116, 58-64. http://dx.doi.org/10.1055/s-2007-985367

[142] Kabadi, U.M. (2008) Starting Insulin in Type 2 Diabetes: Overcoming Barriers to Insulin Therapy. International Journal of Diabetes in Developing Countries, 28, 65-68. http://dx.doi.org/10.4103/0973-3930.43102

[143] Kabadi, U.M. (2008) Deleterious Outcomes after Abrupt Transition from Insulin Glargine to Insulin Determir in Patients with Type 1 Diabetes Mellitus. Clinical Drug Investigation, 28, 697-701.

[144] Ligthelm, R.J., Gylvin, T., DeLuzio, T. and Raskin, P. (2011) A Comparison of Twice-Daily Biphasic Insulin Aspart $70 / 30$ and Once-Daily Insulin Glargine in Persons with Type 2 Diabetes Mellitus Inadequately Controlled on Basal Insulin and Oral Therapy: A Randomized, Open-Label Study. Endocrine Practice, 17, 41-50. http://dx.doi.org/10.4158/EP10079.OR

[145] Buse, J.B., Bergenstal, R.M., Glass, L.C., Heilmann, C.R., Lewis, M.S., Kwan, A.Y., Hoogwerf, B.J. and Rosenstock, J. (2011) Use of Twice-Daily Exenatide in Basal Insulin-Treated Patients with Type 2 Diabetes: A Randomized, Controlled Trial. Annals of Internal Medicine, 154, 103-112. http://dx.doi.org/10.7326/0003-4819-154-2-201101180-00300

[146] Kabadi, U.M. (2011) Iowa Medicaid 2: Lapse of Glycemic Control on Abrupt Transition from Insulin Glargine to Insulin Detemir in Type 2 Diabetes Mellitus. Journal of Diabetes Mellitus, 1, 124-128. http://dx.doi.org/10.4236/jdm.2011.14017

[147] Thong, K.Y., Jose, B., Sukumar, N., Cull, M.L., Mills, A.P., Sathyapalan, T., Shafiq, W., Rigby, A.S., Walton, C. and Ryder, R.E., ABCD Nationwide Exenatide Audit Contributors (2011) Safety, Efficacy and Tolerability of Exenatide in Combination with Insulin in the Association of British Clinical Diabetologists Nationwide Exenatide Audit. Diabetes, Obesity and Metabolism, 13, 703-710. http://dx.doi.org/10.1111/j.1463-1326.2011.01393.x

[148] Ved, P. and Shah, S. (2012) Evaluation of Vildagliptin and Fixed Dose Combination of Vildagliptin and Metformin on Glycemic Control and Insulin Dose over 3 Months in Patients with Type 2 Diabetes Mellitus. Indian Journal of Endocrinology and Metabolism, 16, S110-S113. http://dx.doi.org/10.4103/2230-8210.94258

[149] Rizos, E.C., Ntzani, E.E., Papanas, N., Tsimihodimos, V., Mitrogianni, Z., Maltezos, E. and Elisaf, M.S. (2012) Combination Therapies of DPP4 Inhibitors and GLP1 Analogues with Insulin in Type 2 Diabetic Patients: A Systematic Review. Diabetes, Metabolic Syndrome and Obesity, 5, 165-174.

[150] Levin, P., Wei, W., Wang, L., Pan, C., Douglas, D. and Baser, O. (2012) Combination Therapy with Insulin Glargine and Exenatide: Real-World Outcomes in Patients with Type 2 Diabetes. Current Medical Research and Opinion, 28, 439-446. http://dx.doi.org/10.1185/03007995.2012.654850

[151] Levin, P.A., Mersey, J.H., Zhou, S. and Bromberger, L.A. (2012) Clinical Outcomes Using Long-Term Combination Therapy with Insulin Glargine and Exenatide in Patients with Type 2 Diabetes Mellitus. Endocrine Practice, 18, 17-25. http://dx.doi.org/10.4158/EP11097.OR

[152] Giampietro, O., Giampietro, C., Bartola, L.D., Masoni, M.C. and Matteucci, E. (2013) Sitagliptin as Add-On Therapy in Insulin Deficiency: Biomarkers of Therapeutic Efficacy Respond Differently in Type 1 and Type 2 Diabetes. Drug Design, Development and Therapy, 7, 99-104.

[153] Rizos, E.C., Ntzani, E.E., Papanas, N., Tsimihodimos, V., Mitrogianni, Z., Maltezos, E. and Elisaf, M.S. (2013) Combination Therapies of DPP4 Inhibitors and GLP1 Analogues with Insulin in Type 2 Diabetic Patients: A Systematic Review. Current Vascular Pharmacology, 11, 992-1000. http://dx.doi.org/10.2174/15701611113119990103

[154] Buturovic, B.A., Ristic, L.B. and Narancic, A.M. (2014) Effects of Therapy with Basal Insulin Analogues Combined with GLP 1 Analogues and Metformin in the Treatment of Obese Patients with Poorly Regulated Postprandial Glycemia. Medical Archives, 68, 313-316. http://dx.doi.org/10.5455/medarh.2014.68.313-316

[155] Buse, J.B., Han, J., Miller, S., MacConell, L., Pencek, R. and Wintle, M. (2014) Addition of Exenatide BID to Insulin Glargine: A Post-Hoc Analysis of the Effect on Glycemia and Weight across a Range of Insulin Titration. Current Medical Research and Opinion, 30, 1209-1218. http://dx.doi.org/10.1185/03007995.2014.896329

[156] Ito, D., Inoue, K., Kaneko, K., Yanagisawa, M., Sumita, T., Ikegami, Y., Awata, T., Ishida, H., Katayama, S. and Inukai, K. (2015) The Efficacy of Vildagliptin Concomitant with Insulin Therapy in Type 2 Diabetic Subjects. Journal of 
Clinical Medicine Research, 7, 303-307. http://dx.doi.org/10.14740/jocmr2057w

[157] Home, P.D., Bolli, G.B., Mathieu, C., Deerochanawong, C., Landgraf, W., Candelas, C., Pilorget, V., Dain, M.P. and Riddle, M.C. (2015) Modulation of Insulin Dose Titration Using a Hypoglycaemia-Sensitive Algorithm: Insulin Glargine versus Neutral Protamine Hagedorn Insulin in Insulin-Naïve People with Type 2 Diabetes. Diabetes, Obesity and Metabolism, 17, 15-22. http://dx.doi.org/10.1111/dom.12329

[158] Kabadi, U.M. (2015) Better Glycemic Control with Lesser Hypoglycemia on Transition of Insulin Glargine Administration from Bedtime to Morning in Type 2 Diabetes Mellitus. Annual Meeting Abstract No. 2538, American Diabetes Association, Alexandria, VA.

[159] Zhang, Y., McCoy, R.G., Mason, J.E., Smith, S.A., Shah, N.D. and Denton, B.T. (2014) Second-Line Agents for Glycemic Control for Type 2 Diabetes: Are Newer Agents Better? Diabetes Care, 37, 1338-1345. http://dx.doi.org/10.2337/dc13-1901

[160] International Diabetes Federation (2015) Diabetes Atlas. 